Vol. 8, n 1 | 2004

Varia

\title{
Jean-Noël Luc (ed.), Figures de Gendarmes, Sociétés et Représentations
}

No. 16, Paris, CREDESS, 2003, 378 pp., ISSN 12622966.

\section{Clive Emsley}

\section{(2) OpenEdition}

\section{Journals}

Electronic version

URL: https://journals.openedition.org/chs/527

DOI: $10.4000 /$ chs. 527

ISSN: $1663-4837$

Publisher

Librairie Droz

Printed version

Date of publication: 1 August 2004

Number of pages: 114-116

ISBN: 2-600-00955-8

ISSN: $1422-0857$

\section{Electronic reference}

Clive Emsley, "Jean-Noël Luc (ed.), Figures de Gendarmes, Sociétés et Représentations", Crime, Histoire \& Sociétés / Crime, History \& Societies [Online], Vol. 8, $n^{\circ} 1$ | 2004, Online since 20 February 2009, connection on 23 March 2022. URL: http://journals.openedition.org/chs/527 ; DOI: https://doi.org/ $10.4000 /$ chs. 527

This text was automatically generated on 23 March 2022.

(C) Droz 


\title{
Jean-Noël Luc (ed.), Figures de Gendarmes, Sociétés et Représentations
}

No. 16, Paris, CREDESS, 2003, 378 pp., ISSN 12622966.

\author{
Clive Emsley
}

\section{REFERENCES}

Jean-Noël Luc (ed.), Figures de Gendarmes, Sociétés et Représentations, No. 16, Paris, CREDESS, 2003, 378 pp., ISSN 12622966.

1 'Je demande à voir tes papiers'. With these words the retired gendarme brigadier Dussutour, veteran of the Crimea and Napoleon III's Italian adventures, confronts the Prussian army in 1870, and simultaneously concludes Léon Bloy's short story Le bon gendarme. Bloy's Dussutour is courageous, but his intention to halt the Prussian advance in this manner is comic, not to say ridiculous. The story, however, as François Dieu make plain in the conclusion to this illuminating collection of essays, says much about the perceptions of the gendarme in France at the end of the nineteenth century and subsequently.

2 Figures de Gendarmes, a special edition of the journal Sociétés et Représentations edited by Jean-Noël Luc, presents a score of essays analysing the ways in which the Gendarmerie nationale has sought to portray itself and how it has been portrayed by others since the closing years of the old regime. The source material explored in the various chapters ranges widely from official journals and recruiting posters to marionette plays, popular songs and the affectionate film series Le Gendarme de Saint-Tropez. Cyril Cartayrade delves into marriage registers held by both the Gendarmerie and in the archives of Puyde-Dôme as a way into establishing the situation of the gendarme-as-bridegroom; he thus opens a new perspective on the way in which the gendarme was regarded in the community to which he was posted. The essays assess also the images that developed in 
the rivalry and friction that sometimes have soured relations between the police and the Gendarmerie, and the sullied image (and attempts to burnish it) of the Gendarmerie as a result of its duties during the First World War. Two chapters on representations of the Garde nationale under the July Monarchy and during the Commune, and a third on the image of the garde-champêtre, do not relate directly to the Gendarmerie but nevertheless encourage the reader to draw fruitful parallels. If there is a gap in the coverage, it is in the early nineteenth century. Possibly the Napoleonic period has now been reasonably well worked, but it would have completed the picture to have something from this period. Also, perhaps, it would have been interesting to have some assessment of the image of the corps presented in Cochet de Savigny's Le Journal de la Gendarmerie, which began publication in 1839 and continued under his direction into the Second Empire.

The chapters are of a consistently high quality. Discussing each one in detail would extend this review beyond reasonable limits, so I will confine myself to drawing out some of the key themes. Gendarmes are soldiers and the image of the élite military man appears time and again as a key element in the institution's self-image. In the late nineteenth century it was the image of the uniformed soldier of the law that was contrasted with the dubious behaviour and secretive practices of civilian police officers unidentifiable through their lack of a uniform. Military bearing, courage, love of the motherland were central again following the Gendarmerie's role as provosts during the First World War - 'the front stops at the first gendarme' was the poilu's quip - and also following the trauma of the Second World War and the wars of independence in the colonies. A shift to a less military image, with less focus on the role of maintaining public order came in the last third of the twentieth century. This coincided with the recruitment of women into the corps which is usefully touched upon in the volume, though it might also be linked with some wider developments within European societies in general. While the Gendarmerie revelled in its élite military nature, this was, for many of its critics, its main problem. The pig-headed, narrowly focussed military man who insisted on doing everything by the book was a both a figure of fun and a figure who exuded oppression. This critical perception was also linked with the assumption of the gendarme being a peasant in uniform. But here again, there were two sides to the image. While the peasant soldier-policeman might be dangerously and foolishly blinkered or a figure of fun, he could also reflect a particular, affectionate image of France herself. This was the image of quiet, rural, conservative country, an image that was to be found as late as the 1970s in the character of Cruchot, the 'gendarme of Saint-Tropez'. At times the institution has sought to distance itself from this image. At the beginning of the twentieth century, for example, with Clemenceau's creation of the technological mobile detective brigades apologists for the Gendarmerie stressed how the force complemented these new institutions with its own role of protector of the community. In the inter-war years the stress was on the Gendarmerie's own technological advances in the area of crowd control. Towards the end of the twentieth century, alongside the caring, family-man gendarme, there was also the 'super hero' gendarme equipped with the latest weaponry in the fight against terrorism. However, the moment that the 'super hero' made an error - as in the bizarre incident of the Corsican affaire des paillotes in April 1999 - parts of the press resorted to old images of the marionette show and the clumsy soldier, while others turned to notions of honest soldiers following the suspect orders of politicians. 
4 A more general reflection is generated by these essays, namely how similar the images of European police institutions often seem to be. Many working-class labels applied to police officers in the nineteenth and early twentieth centuries suggest the perception of a tough oppressor - cogne (for the gendarme), Bulle (for the Schutzmann), crusher (for the Bobby). The English Bobby has commonly been celebrated as a unique representation of certain kinds of Englishness; but he is also represented as a none-toobright, narrowly focussed 'plod'. The Italian Carabinieri appear to have gone through identity and image crises in much the same way as the Gendarmerie. It has been feted at one moment, and ignored the next; denigrated for its role in the First World War; praised as the most honest element of the Italian state; ridiculed as composed of ignorant peasants from the south. This collection suggests that there is much more that can be done in opening up these issues beyond national frontiers.

\section{AUTHORS}

\section{CLIVE EMSLEY}

The Open University, Milton Keynes, c.emsley@open.ac.uk 